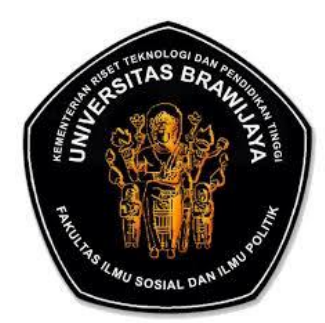

\title{
Fungsi Pengawasan Parlemen dalam Perspektif Gender ${ }^{1}$
}

\author{
Abdul Aziz SR ${ }^{2}$ \\ Program Studi Ilmu Politik, Universitas Brawijaya, Malang, Indonesia \\ abdulazizsr@ub.ac.id
}

\begin{abstract}
As a branch of power in a democratic system, parliament has a function of control over the executive. This function is carried out to ensure that what is ordered by the Act is carried out properly by the executive, as well as to prevent at least minimizing deviations of power. In a gender perspective, the supervision carried out by parliament must accommodate and consider all interests for justice for all citizens. The interests of all citizens without discrimination against both men and women. Legislative activities and budget allocations carried out by the parliament together with the government must form a unity with a supervisory function to ensure the decision-making process along with political decisions that are gender responsive.
\end{abstract}

Keywords: parliamentary oversight, democracy, gender responsiveness.

\begin{abstract}
Abstrak
Sebagai cabang kekuasaan dalam sistem demokrasi, parlemen memiliki fungsi kontrol terhadap eksekutif. Fungsi ini dilakukan untuk memastikan bahwa apa yang diperintahkan oleh Undang-Undang dilaksanakan dengan baik oleh eksekutif, sekaligus untuk mencegah setidaknya meminimalisasi penyimpangan-penyimpangan kekuasaan. Dalam perspektif gender, pengawasan yang dilakukan parlemen harus mengakomodasi dan mempertimbangkan kepentingan semua untuk keadilan bagi semua warga. Kepentingan semua warga tanpa diskriminasi baik terhadap laki-laki maupun perepempuan. Kegiatan legislasi dan pengalokasian anggaran yang dilakukan parlemen bersama pemerintah mesti membentuk satu kesatuan dengan fungsi pengawasan untuk menjamin proses pengambilan keputusan berikut keputusan-keputusan politik yang terbentuk responsif gender.
\end{abstract}

Kata kunci: pengawasan parlemen, demokrasi, responsif gender.

1 Tulisan ini dikembangkan dari paper yang semula dipresentasikan dalam Focused Group Discussion "Pemahaman tentang Parlemen untuk Calon Anggota Legislatif" oleh Kementerian Pemberdayaan Perempuan dan Perlindungan Anak Republik Indonesia, di Hotel Grand Saviro, Bogor, 26-27 September 2018.

${ }^{2}$ Penulis juga merupakan Senior Researcher pada Center for Election and Political Party (CEPP) FISIP UI, Depok. 


\section{PENDAHULUAN}

Dalam politik, parlemen (parliament) memiliki beberapa sebutan lain seperti majelis (assembly), legislatif (legislative) atau legislator (legislature), Dewan Perwakilan Rakyat (People's Representative Body) (Budiarjo, 2008;315), juga houses, dan chamber (Newton dan Deth, 2016;77). Kendati sebutan-sebutan itu dimaksudkan untuk memberikan tekanan tertentu pada lembaga kekuasaan tersebut, tetapi sesungguhnya keberadaannya menjadi simbol dari kedaulatan rakyat (Budiarjo, 2008;315). Sebutan-sebutan itu merujuk kepada hal yang sama; [i] assembly merupakan tempat berkumpulnya para perwakilan terpilih yang mengadakan rapat mengenai urusan publik, [ii] parliament merupakan tempatnya orang "mengobrol", [iii] house dan chamber merupakan tempat di mana assembly dan parliament bertemu - bisa Majelis Rendah (House of Common), Majelis Tinggi (House of Resentatives), dan Dewan Legislatif Rendah (Chamber of Deputies) di beberapa parlemen (Newton dan Deth, 2016;94).

Di Indonesia parlemen menggunakan sebutan Dewan Perwakilan Rakyat (anggotanya dari partai politik), Dewan Perwakilan Daerah (anggotanya dari perseorangan dan non partai politik) ${ }^{3}$, dan Majelis Permusyawaratan Rakyat (anggotanya gabungan antara DPR dan DPD). Sebutan itu mendapat pengaruh dari bahasa Arab dan tradisi kaum Muslim yang mayoritas di negeri ini.

Istilah parlemen (dari bahasa Prancis parler, yang berarti berbicara) terkadang lebih dipilih karena ia menghindari keterbatasan-keterbatasan istilah "majelis" serta kerancuan dalam istilah "legislator". Juga mengisyaratkan bahwa badan-badan ini memiliki sebuah karakter yang sangat khas. Ia mengimplikasikan di manaciri utamanya adalah bahwa mereka merupakan badan-badan konsultatif atau deliberatif. Terlepas dari kekuasaan-kekuasaan legislatif mereka dan ciri-ciri perwakilan mereka, yaitu forum di mana kebijakan dan isu-isu politik dapat secara terbuka dibahas dan diteliti (Heywood, 2014;547).

Parlemen merupakan salah satu cabang kekuasaan dalam sistem politik demokrasi. Demokrasi menghendaki kekuasaan tidak memusat di satu lembaga apalagi di satu tangan. Ia (kekuasaan) haruslah terbagi dan/atau terpisah ke beberapa lembaga politik (formal) dengan fungsi yang berbeda, misalnya selain parlemen (legislatif) juga ada eksekutif dan yudikatif. Hal ini sekaligus untuk menjaga tetap terpeliharanya kondisi check and balances dalam kehidupan politik suatu negara.

Sebagai negara demokrasi, Indonesia sudah mengenal dan memiliki lembaga parlemen sejak usia kemerdekaannya masih sangat belia. Pernah ada

\footnotetext{
${ }^{3}$ Dalam praktik, terdapat anggota DPD yang juga aktivis partai politik seperti Oesman Sapta Odang yang menjabat Ketua Umum Partai Hanura. Pada Pemilu 2019 Oesman Sapta kembali mencalonkan diri sebagai anggota DPD dari Provinsi Kalimantan Barat. Kontroversi sebetulnya, namun Mahkamah Agung mengabulkan uji materi yang diajukan Oesman terhadap PKPU No. 26/2018 tentang Pencalonan Perserta Pemilu Dewan Perwakilan Daerah. Oesman pun berhak maju sebagai calon anggota DPD, dan KPU diperintahkan memasukkan (kembali) nama Oesman dalam daftar calon anggota DPD.
} 
KNI(P) Komite Nasional Indonesia (Pusat), kendati tidak total berperan sebagai lembaga perlemen karena mirip-mirip juga sebagai lembaga pembantu pemerintah. Ketika itu bersamaan dengan berlangsungnya sistem parlementer.Kemudian, kita juga mengenal DPR dan Konstituante hasil Pemilihan Umum 1955. Selanjutnya terbentuk DPR (dan MPR) hasil pemilu-pemilu Orde Baru sejak 1971 hingga Pemilu 1997. Di era reformasi parlemen juga dibentuk secara teratur sejak Pemilu 1999 hingga sekarang.

Parlemen-parlemen di negeri ini diharapkan selain menjadi kekuatan politik yang turut menjamin keberlangsungan dan pelembagaan demokrasi, juga menjadi lembaga kekuasaan yang mampu merepresentasikan secara riil dan sungguhsungguh tuntutan dan kegelisahan-kegelisahan rakyat untuk mendapat tempat di dalam kebijakan negara. Fungsi-fungsi serta kewajiban politik yang melekat dalam diri parlemen sepenuhnya dihajatkan untuk mengartikulasikan kepentingan publik.Fungsi pengawasan yang dimiliki parlemen, misalnya, pada dasarnya dihajatkan untuk menjaga dan menyelamatkan kepentingan publik/rakyat dari penyelewengan kekuasaan.

Salah satu kepentingan publik yang harus menjadi perhatian parlemen adalah soal keadilan gender. Keadilan gender hingga saat ini masih jauh dari harapan. Untuk itu, di satu sisi, perlu menjadi bagian dari isu sosial dan politik yang harus diangkat dan diperjuangkan secara serius oleh parlemen. Di sisi lain, isu-isu gender yang sejauh ini sudah menjadi bagian dalam agenda-agenda kebijakan perlu menjadi fokus pengawasan tersendiri bagi parlemen agar kebijakan-kebijakan tersebut memberi makna dan dampak yang lebih signifikan bagi terwujudnya keadilan gender. Dengan kata lain, keputusan-keputusan politik dan/atau kebijakan-kebijakan sensitifitas gender perlu mendapat perhatian tersendiri dalam pengawasan parlemen. Tulisan ini secara khusus berbicara tentang fungsi pengawasan parlemenberbasis responsif gender.

\section{HASIL DAN PEMBAHASAN}

\section{A. Sedikit tentang Perspektif Gender}

Konsep gender (gender) berbeda dengan konsep seks (sex) atau jenis kelamin. Seks merupakan sifat serta pembagian dua jenis kelamin yang berbeda secara biologis. Ia merupakan pemberian alam dan menjadi kodrat setiap manusia. Ia melekat dengan sendirinya secara alamiah pada setiap manusia yang tidak bisa diganggu-gugat apalagi dipertukarkan. Dikenallah kemudian pembelahan antara laki-laki dan perempuan. Tetapi, keduanya merupakan pasangan (partner) jenis, bukan lawan (versus) jenis. Laki-laki dengan ciri-ciri fisiknya sendiri, perempuan dengan ciri-ciri fisiknya sendiri pula; keduanya dalam banyak hal berbeda. Perbedaan-perbedaan fisik (biologis) yang ada itu sekaligus menunjukkan perbedaan fungsi (dalam konteks reproduksi, misalnya)antara keduanya yang sifatnya saling melengkapi dan menyempurnakan.Dalam konteks jenis kelamin yang berbeda antara laki-laki dan perempuan itu pula yang memungkinkan 
kehidupan umat manusia berkembang-biak sebagai mahluk hidup dari generasi ke generasi dalam rentang sejarah dan peradaban yang sangat panjang sejak Nabi Adam AS hingga saat ini dan mendatang.

Sementara itu, gender lebih menunjuk pada relasi di mana laki-laki dan perempuan dalam berinteraksi, sehingga yang dipersoalkan tidak hanya perempuan melainkan juga laki-laki (Abdullah, 2001;23). Gender juga merupakan sifat yang melekat pada laki-laki maupun perempuan sebagai hasil konstruksi sosial dan budaya. Biasanya terjadi perlakuan yang berbeda terhadap perempuan sebagai hasil interaksi sosial dan budaya yang merugikan perempuan. Maknanya bisa berbeda-beda di berbagai masyarakat, tetapi umumnya konstruksi itu merugikan perempuan. Yang paling penting adalah bahwa mempermasalahkan konstruksi gender bukan sekadar membicarakan urusan perempuan, melainkan upaya untuk menghasilkan relasi yang adil bagi laki-laki dan perempuan (Gerung, Nurjannah, dan Sudibyo, 2015;4).

Mengacu padastudi Connel, Carver menyebutkan, dalam seratus tahun terakhir ini, seks telah ditetapkan sebagai kategori "biologis", yang konon berasal dari pengamatan tubuh. Gender sering - meskipun tidak eksklusif dianggapsebagai kategori "sosiologis" yang merujuk pada cara-cara di mana perilaku seksual dimanifestasikan oleh individu dalam kehidupan sosial. Kemudian, dalam sekitar lima puluh tahun terakhir, analisis dan politik feminis telah mengangkat isu "gender" dalam konteks cara-cara di mana perempuan ditindas atau paling tidak dirugikan oleh laki-laki secara individu dan kolektif, dan cara-cara di mana praduga menyeluruh tentang laki-laki dan perempuan, maskulinitas dan feminitas, bekerja untuk membentuk dan mereproduksi perilaku ini (Carver, 2005;14-15).

Dalam kontes gender, segala sesuatu yang melekat baik pada laki-laki maupun perempuan bukan karena hadir secara alamiah melainkan karena dilabelkan dan diberikan oleh manusia itu sendiri dalam lingkungan sosial dan budaya. Misalnya label perempuan lebih perasa, emosional, lembut, lebih domestik, dan lain-lain; sementara laki-laki lebih keras, tegas, rasional, lebih publik, dan lain-lain. Sebagai hasil konstruksi, maka segala yang disifatkan itu sewaktu-waktu memang dapat dipertukarkan - walau terkadang tak mudah. Mengapa tak mudah? Bisa karena laki-laki masih dominan dan ingin tetap mempertahankan dominasinya, bisa juga karena perempuan sendiri memberikan dukungan terhadap hasil konstruksi itu.

Untuk konteks Indonesia, ajaran-ajaran (piwulang) yang tertulis dalam karya sastra Jawa seperti diSerat Wulang Putri, Serat Centhini, dan Serat Cendrarini, misalnya, besar kemungkinan cukup kuat memengaruhi cara berpikir dan bersikap masyarakat kita menyangkut relasi laki-laki dan perempuan baik dalam kehidupan sosial maupun rumah tangga. Serat-serat itu ditulis oleh para pujangga keraton atas perintah raja, dan berbicara soal kedudukan perempuan dalam lingkungan (sosial) mereka. Perempuan dilukiskan sebagai sosok manusia 
yang sepenuhnya berada dalam radius-kendali kekuasaan laki-laki. Perempuan ditempatkan sebagai subordinasi laki-laki. Kedudukan sosial laki-laki jauh lebih tinggi dibanding perempuan. Laki-laki mutlak sebagai pemimpin, sementara perempuan mutlak sebagai pengikut. Segala yang dikehendaki dan diperbuat perempuan harus seizin dan atas perintah laki-laki (suami).

Apa yang dikonstruk oleh pujangga-pujangga Keraton (Jawa) dalam seratserat itu tentu sepenuhnya merupakan perspektif laki-laki dan kekuasaan soal perempuan. Konstruk sosial-budaya dan perspektif tersebut turut memengaruhi konstruk berpikir masyarakat luas, terutama di Jawa, dalam memandang posisi sosial perempuan. Sampai saat ini, pengaruh serat-serat itu masih cukup terasa dalam masyarakat kita. Kuatnya sikap nriman (menerima) di kalangan perempuan (isteri) terhadap realitas laki-laki (suami), misalnya, merupakan salah satu contoh yang disebut. Bisa jadi, rendahnya tingkat partisipasi politik perempuan di Inonesia hingga saat ini turut disumbangkan oleh konstruk pemikiran yang diwariskan olehserat-serat tersebut.

Pandangan demikian sesungguhhnya bukan sesuatu yang baru. Ia sudah berusia sangat tua dalam peradaban masyarakat manusia. De Beauvoir, mengutip pandangan Aristoteles yang menyebutkan "The female isfemalebyvirtueof acertain lack of qualities. We shouldregardwomen'snatureas suffering fromnaturaldefectiveness."Jadi, perempuan selain kurang berkualitas, juga sebagai wujud ketidaksempurnaan alam. Sementera St. Thomas memandang perempuan sebagai "incomplete man," (laki-laki yang tidak sempurna) dan "incidental being” (tak sengaja tercipta). Itu pula yang disimbolkan dalam Kitab Kejadian di mana Hawa (Eve) dilukiskan Bossuet sebagai mahluk yang diciptakan dari Adam 's “supernumerary" (tulang rusuk Adam) (Bauevoir, 2010;25).

Pengaruh dari pandangan tersebut masih ada dan terasa hingga saat ini, dan pada gilirannya turut memperkuat perbedaan bahkan kesenjangan gender dalam masyarakat, termasuk dalam masyarakat politik (polity). Perbedaan gender sesungguhnya tidaklah menjadi masalah sepanjang tidak melahirkan ketidakadilan gender (gender inequality). Namun, yang menjadi persoalan, ternyata perbedaan gender telah melahirkan berbagai ketidakadilan, baik bagi kaum laki-laki dan terutama terhadap perempuan. Ketidakadilan gender merupakan sistem dan struktur di mana baik laki-laki maupun perempuan menjadi korban dari sistem tersebut. Ketidakadilan gender termanifestasikan dalam berbagai bentuk ketidakadilan, seperti: marginalisasi atau proses pemiskinan ekonomi, subordinasi atau anggapan tidak penting dalam keputusan politik, pembentukan stereotipe atau melalui pelabelan negatif, kekerasan (violence), serta sosialisasi ideologi nilai peran gender (Faqih, 1996;12-13).

Berangkat dari kenyataan tersebut, setidaknya dua agenda yang perlu dilakukan. Pertama, melawan hegemoni yang merendahkan perempuan, dengan cara melakukan dekonstruksi ideologi. Kedua, melawan paradigma developmentalism yang berasumsi bahwa keterbelakangan kaum perempuan 
disebabkan karena mereka tidak berpartisipasi dalam pembangunan. Perempuan pun dianggap sebagai objek pembangunan, yakni diidentifikasi, diukur, dan diprogramkan (Faqih, 1996;152-153).

Perspektif gender kemudian dapat dipahami sebagai cara berpikir dengan melihat bahwa ada pensifatan yang berbeda antara laki-laki dan perempuan sebagai hasil konstruksi sosial, kemudian dilanjutkan dengan upaya-upaya merekayasa hasil konstruksi sosial tersebut untuk tujuan keadilan gender.

\section{B. Fungsi Pengawasan Parlemen}

Parlemen sesungguhnya memiliki banyak fungsi, seperti:fungsi legislasi, perwakilan, pengawasan, rekrutmen politik, dan legitimasi. Legislasi seringkali dipandang sebagai fungsi utama dari parlemen, yang secarajelas diimplikasikan oleh klasifikasi umum mereka sebagai legislator. Parlemen juga memainkan peran sebagai perwakilan yang penting dalam menyediakan sebuah penghubung antara pemerintah dan rakyat. Di samping itu, parlemen pun berperan sebagai lembaga yang mengawasi kekuasaan eksekutif. Dalam konteks ini, parlemen terlihat jelas sebagai badan-badan pengawas, yang peran utamanya adalah untuk menghasilkan akuntabilitas. Fungsi rekrutmen dari parlemen hadir dalam wujud sebagai saluransaluran utama rekrutmen, menyediakan sebuah wadah bagi para politisi berbakat dari mana para pembuat keputusan terkemuka akan muncul. Terakhir, fungsi legitimasi dari parlemen di mana lembaga ini hadir untuk meningkatkan legitimasi dari sebuah rezim dengan mendorong publik untuk memandang sistem kekuasaan yang ada sebagai kekuasaan yang "absah". Legitimasi sungguh penting. Itu sebabnya mengapa negara-negara otoritarian - atau bahkan totalitarian sekalipuntetap memiliki parlemen, meskipun tidak memiliki independensi legislatif atau kekuasaan pembuatan kebijakan, dan itu untuk legitimasi (Heywood, 2014;553$560)$.

Secara formal, fungsi parlemen yang disebutkan dalam Konstitusi (UUD 1945) dan UU MD3 adalah fungsi legislasi, fungsi pengawasan, dan fungsi anggaran. Dalam praktik kekuasaan, selain ketiga fungsi tersebut, fungsi-fungsi yang lain dari parlemen (perwakilan, rekrutmen politik, dan legitimasi) menjadi kenyataan yang sulit dibantah. Dengan kata lain, parlemen melakukan semua fungsi-fungsi tersebut. Pembahasan dalam tulisaninidibatasi pada soal fungsi pengawasan dari parlemen saja.

\section{Makna, Objek, dan Tujuan Pengawasan Perlemen}

Pengawasan parlemen dapat dimaknai sebagai fungsi parlemen (DPR dan DPD) untuk melakukan kontrol terhadap pemerintah (eksekutif) menyangkut pelaksanaan Undang-Undangserta Anggaran Pendapatan dan Belanja 
Negara. ${ }^{4}$ Pengawasan parlemen merupakan pengawasan politik, bukan pengawasan administrasi dan teknis. UU dan APBN dibentuk bersama oleh parlemen dan pemerintah, sehingga parlemen pada dasarnya juga ikut bertanggung jawab terhadap kedua produk politik tersebut. Wujud tanggung jawabnya adalah ikut mengawasi untuk memastikan bahwa pemerintah benarbenar melaksanakan UU dan APBN tersebut dengan baik.Di tingkat daerah, parlemen daerah (DPRD Provinsi dan Kabupaten/Kota) melakukan pengawasan terhadap: [1] pelaksanaan Peraturan Daerah dan peraturan perundang-undangan lainnya; [2] Peraturan Kepala Daerah; [3] APBD;[4] kebijakan Pemerintah Daerah dalam melaksanakan program pembangunan daerah; dan [5] kerjasama internasional di daerah. ${ }^{5}$

Fungsi pengawasan - termasuk fungsi-fungsi lainnya - dari parlemen berkaitan dan bertali-temali dengan hak-hak yang melekat pada parlemen baik sebagai lembaga maupun anggota, yakni: hak interpelasi, hak angket, dan hak menyatakan pendapat.Apa hubungannya antara fungsi pengawasan dan hak-hak parlemen? Hak-hak tersebut menjadi salah satu mekanisme bagi parlemen untuk melakukan kontrol terhadap pemerintah. Menggunakan hak-hak yang melekat pada dirinya sekaligus sebagai bentuk dari pengawasan parlemen terhadap pemerintah. Dengan kata lain, hak-hak tersebut menjadi media bagi parlemen untuk melakukan pengawasan. Bentuk lain dari pengawasan parlemen adalah melakukan berbagai bentuk rapat baik dengan pemerintah dan badan hukum maupun dengan warga negara.

Objek yang menjadi fokus pengawasan parlemen terdiri atas tiga hal, yakni:[1] pelaksanaan anggaran yang ditetapkan dalam APBN/APBD; [2] kebijakan pemerintah (dan pemerintah daerah); dan [3] penerbitan peraturan pelaksana yang diperintahkan oleh undang-undang maupun peraturan daerah.Lebih spesifik, untuk parlemen daerah (DPRD), fokus pengawasan APBD, meliputi: [1] rencana program (kegiatan); dan [2] pelaksanaan dari rencana program/kegiatan.

Lalu, untuk apa atau apa pentingnya pengawasan parlemen? Keutamaan pengawasan parlemen adalah untuk sebuah akuntabilitas politik. Ia berusaha mencegah dan menghindari terjadinya penyimpangan-peyimpangan atau penyelewengan-penyelewengan dalam pelaksanaan UU dan APBN/APBD. Melalui pengawasan (politik), parlemen hendak dan berusaha memastikan bahwa pelaksanaan UU dan realisasi APBN/APBD berjalan dengan baik dan dapat dipertanggungjawabkan.

Dalam tatakelola negara dan praktik kekuasaan cenderung terjadi penyimpangan-penyimpangan. Lord Acton, misalnya, berteori bahwa kekuasaan cenderung korup, dan kekuasaan absolut akan korup secara mutlak pula. Power

\footnotetext{
${ }^{4}$ Lihat, UUD 1945, pasal 20A; dan UU No. 17 Tahun 2014 tentang MPR, DPR, DPD, dan DPRD, pasal 70 (selanjutnya disebut UU MD3).

${ }^{5}$ Lihat, UU No. 32 Tahun 2004 tentang Pemerintahan Daerah, pasal 42.
} 
tends to corrupt and absolute power tends to corrupt absolutely. Ada kecenderungan mengembang pada kekuasaan ini, menyebabkan bahwa masalah kekuasaan pada akhirnya merupakan masalah bagaimana mengekang, membatasi, dan mengawasi kekuasaan itu. Walau demikian, seorang satirist Romawi de Junenal bilang "sed quis custodiet ipsos custodes" (siapa yang akan mengawasi para pengawas) (Isjwara, 1999;55).

Pemikir-pemikir klasik seperti Socrates (399 s.M.), Plato (427-347 s.M.), Aristoteles (384-322 s.M.), dan Cicero (106-43 s.M.) banyak sekali berbicara soal penyimpangan dan ketidakpiawaian para pemimpin dalam menjalankan mandat publik. Pelanggaran-pelanggaran sering dilakukan, dan itu merupakan bentuk dari penyalahgunaan kekuasaan. Dalam konteks inilah pengawasan menjadi penting dan tidak bisa dianggap sepele dalam politik dan penyelenggaraan negara. Ilmuwan politik seperti Catliri bahkan secara tegas menyebut politik sebagai the act of control.

\section{Mekanisme dan Strategi Pengawasan Parlemen}

Sedikit disinggung di atas, pengawasan parlemen berkaitan dengan hak-hak parlemen (sebagai lembaga) seperti hak interpelasi, hak angket, dan menyatakan pendapat. Hak interpelasi adalah hak untuk meminta keterangan kepada Pemerintah mengenai kebijakan Pemerintah yang penting dan strategis serta berdampak luas pada kehidupan bermasyarakat, berbangsa, dan bernegara. Sementara hak angket adalah hak DPR untuk melakukan penyelidikan terhadap pelaksanaan suatu UU dan/atau kebijakan Pemerintah yang berkaitan dengan hal penting, strategis, dan berdampak luas pada kehidupan bermasyarakat, berbangsa, dan bernegara yang diduga bertentangan dengan peraturan perundang-undangan. Sedangkan hak menyatakan pendapatadalah hak DPR untuk menyatakan pendapat atas: [a] kebijakan pemerintah atau mengenai kejadian luar biasa yang terjadi di tanah air atau di dunia internasional; [b] tindak lanjut pelaksanaan hak interpelasi dan hak angket; atau [c] dugaan bahwa Presiden dan/atau Wakil Presiden melakukan pelanggaran hukum baik berupa pengkhianatan terhadap negara, korupsi, penyuapan, tindak pidana berat lainnya, maupun perbuatan tercela, dan/atau Presiden dan/atau Wakil Presiden tidak lagi memenuhi syarat sebagai Presiden dan/atau Wakil Presiden.

Dalam konteks perorangan, anggota parlemen juga memiliki hak-hak seperti mengajukan pertanyaan, hak menyampaikan usul dan pendapat, serta hak imunitas. Pengawasan dapat dilakukan oleh lembaga parlemen dan oleh anggota parlemen. Dalam melakukan fungsi pengawasan, parlemen (DPR/DPD/DPRD) menggunakan alat-alat kelengkapan parlemen seperti komisi, badan, panitia khusus, panitia kerja. Sementara itu, berbagai bentuk rapat juga menjadi bagian dari mekanisme pengawasan parlemen.

Alat-alat kelengkapan parlemen serta penggunaan hak-hak yang melekat pada (anggota) parlemen, tentu juga memiliki mekanisme dan/atau prosedur kerja 
tersendiri dalam pelaksanaannya. Mekanisme tersebut sekaligus menjadi mekanisme atau prosedur bagi parlemen dalam melakukan pengawasanpengawasan terhadap pemerintah. Penggunaan hak-hak perlemen - baik lembaga maupun anggota - sudah memiliki prosedur yang jelas sebagaimana diatur di dalam UU MD3 serta tata tertib parlemen. ${ }^{6}$

Ketika anggota menemukan keadaan atau kondisi - yang secara politik mengharuskandigunakannya hak-hak tersebut, tentu tidak perlu risau dan merasa takut dengan konsekuensi atau dampak terhadap dirinya. Sebab, setiap anggota parlemen dijamin hak imunitasnya. Artinya, anggota parlemen tidak dapat dituntut di depan pengadilan karena pernyataan, pertanyaan, dan/atau pendapat yang dikemukakannya baik secara lisan maupun tertulis di dalam rapat parlemen ataupun di luar rapat parlemen yang berkaitan dengan fungsi, wewenang, dan tugas parlemen.

Di dalam UU MD3 dikatakan, anggota parlemen tidak dapat dituntut di depan pengadilan karena sikap, tindakan, kegiatan di dalam rapat parlemen ataupun di luar rapat parlemen yang semata-mata karena hak dan kewenangan konstitusional parlemen dan/atau anggota parlemen. Anggota parlemen tidak dapat diganti antarwaktu karena pernyataan, pertanyaan, dan/atau pendapat yang dikemukakannya baik di dalam rapat DPR maupun di luar rapat DPR yang berkaitan dengan fungsi serta wewenang dan tugas DPR. Namun, ketentuan tersebut tidak berlaku dalam hal anggota yang bersangkutan mengumumkan materi yang telah disepakati dalam rapat tertutup untuk dirahasiakan atau hal lain yang dinyatakan sebagai rahasia negara menurut ketentuan peraturan perundangundangan. $^{7}$

Secara khusus hendak dikemukakan mengenai fungsi pengawasan yang melekat pada Dewan Perwakilan Daerah. ${ }^{8}$ DPD melakukan pengawasan atas pelaksanaan undang-undang mengenai otonomi daerah, pembentukan, pemekaran dan penggabungan daerah, hubungan pusat dan daerah, pengelolaan sumber daya alam dan sumber daya ekonomi lainnya, pelaksanaan APBN, pajak, pendidikan, dan agama. Fungsi tersebut dijalankan dalam kerangka perwakilan daerah.DPD menyampaikan hasil pengawasannya kepada DPR sebagai bahan pertimbangan untuk ditindaklanjuti.Dalam menjalankan tugas pengawasan, anggota DPD dapat melakukan rapat dengan pemerintah daerah, DPRD, dan unsur masyarakat di daerah pemilihannya.

Pengawasan yang dilakukan DPD meliputi aspek-aspek: [1] mengumpulkan data dan bahan keterangantentang pelaksanaan setiap ketentuan undang-undang baik yang menyangkut aspek sosio-politik maupun aspek yuridis; [2] mengawasi pelaksanaan undang-undang dan APBN; [3] meminta penjelasan/klarifikasi pihakpihak terkait pelaksanaan undang-undang; [4] membahas bersamapejabat yang

${ }^{6}$ Lihat, UU MD3, pasal 218.

${ }^{7}$ Lihat, ibid, pasal 224.

${ }^{8}$ Lihat, ibid., pasal 248 dan 249. 
bertanggung jawab dalam pelaksanaan undang-undang tentang langkah perbaikan dan/atau tindakan korektif jika ternyataditemukan penyimpangan dalam realisasinya; dan [4] memberikan rekomendasi terkait hasil pembahasan baik berkenaan dengan perubahan dan pembuatan regulasi maupun implementasi. ${ }^{9}$ Dalam konteks pengawasan, setiap anggota DPD juga memiliki: [a] hak bertanya; dan [b] hak menyampaikan usul dan pendapat. ${ }^{10}$

Bagaimana dengan pengawasan oleh DPRD Provinsi dan DPRD Kabupaten/Kota? Di dalam UU MD3 disebutkan bahwa wewenang dan tugas DPRD Provinsi, antara lain: [1] melaksanakan pengawasan terhadap pelaksanaan peraturan daerah dan anggaran pendapatan dan belanja daerah provinsi; [2] memberikan pendapat dan pertimbangan kepada pemerintah daerah provinsi terhadap rencana perjanjian internasional di daerah; [3] memberikan persetujuan terhadap rencana kerja sama internasional yang dilakukan oleh pemerintah provinsi; [4] meminta laporan keterangan pertanggungjawaban Gubernur dalam penyelenggaraan pemerintahan provinsi; dan [5] memberikan persetujuan terhadap rencana kerja sama dengan daerah lain atau dengan pihak ketiga yang membebani masyarakat dan daerah. ${ }^{11}$

Sama halnya dengan DPRD Provinsi, DPRD Kabupaten/Kota juga memiliki hak interpelasi, hak angket, dan menyatakan pendapat. Ketiga hak DPRD Kabupaten/Kota tersebut memiliki makna yang sama dengan yang ada pada DPRD Provinsi, hanya pada tingkatan pemerintahan yang berbeda. ${ }^{12}$ Dalam konteks pengawasan, DPRD Kabupaten/Kota juga melekat pula pada setiap anggotaya hak: [a] mengajukan pertanyaan; dan [c] menyampaikan usul dan pendapat. Mekanismenya sama dengan yang ada di DPRD Provinsi. ${ }^{13}$

Selain penggunaan hak-hak tersebut, parlemen juga dapat melakukan pengawasan melalui mekanisme rapat-rapat seperti:rapat kerja, rapat dengar pendapat, rapat dengar pendapat umum, rapat panitia khusus, rapat panitia kerja, rapat tim pengawas, dan bentuk rapat lainnya.Di dalam UUMD3 dikatakan, DPR dalam melaksanakan wewenang dan tugasnya, berhak memanggil pejabat negara, pejabat pemerintah, badan hukum, atau warga masyarakat secara tertulis untuk hadir dalam rapat DPR. Lalu, setiap pejabat negara, pejabat pemerintah, badan hukum, atau warga masyarakat wajib memenuhi panggilan DPR. ${ }^{14}$

Bagaimana strategi pengawasan yang dilakukan oleh parlemen? Pengawasan oleh parlemen diharapkan punya arti dan kontribusi bagi upaya mencegah terjadinya penyelewengan-penyelewengan kekuasaan. Dalam rangka itu, perlu strategi tertentu dalam melakukan pengawasan agar lebih efektif,

\footnotetext{
${ }^{9}$ Lihat, Peraturan Dewan Perwakilan Daerah Nomor 1 Tahun 2014 tentang Tata Tertib, pasal 76.

${ }^{10}$ Lihat, UU MD3, pasal 257.

${ }^{11}$ Lihat, UU MD3, pasal 317, 322, 323, 331-337.

${ }^{12}$ Lihat, ibid., pasal 365, 366, 371, dan 379-387.

13 Lihat, ibid., pasal 372.

${ }^{14}$ Lihat, ibid., pasal 73.
} 
mencapai sasaran, dan hadirnya pertanggungjawaban. Setidaknya ada empat strategi yang dapat dapat dilakukan (Heywood, 2014;557-558):

- Memiliki dan menguasai informasi yang akurat, tepercaya, dan memadai tentang objek yang diawasi. Parlemen dapat mengkases berbagai sumber dalam mendapatkan informasi yang cukup dan tepercaya. Tanpa informasi yang relevan dan memadai, pengawasan menjadi sesuatu yang mustahil dilakukan.

- Memiliki sumberdaya yang baik serta memiliki akses ke lembaga-lembaga birokrasi, lembaga-lembaga penelitian, kampus-kampus, media, dan para ahli. Termasuk tenaga ahli yang dimiliki parlemen mesti terjamin kualitas diri dan kinerjanya sehingga dapat mendukung secara optimal kegiatan pengawasan parlemen.

- Memanfaatkan dengan baik dan tepat hak-hak yang melekat pada dirinya, terutama hak interpelasinya. Ketika interpelasi terjadi maka galilah keterangan sebanyak-banyaknya dan sedetail mungkin untuk mendapatkan penjelasan yang tuntas.

- Memiliki kemampuan berbicara secarabaik, logis, sistematis, dan mampu berdebat dengan meyakinkan.

- Memanfaatkan media massa (cetak, elektronik, dan media sosial) untuk menyampaian pandangan-pandangan serta kritik terhadap kebijakankebijakan pemerintah secara dewasa dan bertanggung jawab.

\section{E. Pengawasan Parlemen Responsif Gender}

Di manakah dan bagaimanakah parlemen meletakkan prinsip-prinsip dan nilai-nilai gender dalam pengawasan yang dilakukannya?Gender sesungguhnya bukanlah persoalan eksklusif dan bukan sesuatu yang sangat khusus dalam kehidupan sosial dan politik. Bukan pula hanya urusan kelompok tertentu. Ia menjadi persoalan bersama. Persoalan bangsa. Lembaga kekuasaan seperti parlemen tentu dituntut komitmen dan tanggung jawab yang lebih besar dalam menangani persoalan gender.

Jika gender lebih pada soal relasi sosial, maka sebenarnya ia muncul dalam semua konteks kehidupan bernegara, berbangsa, dan bermasyarakat. Ia ada di partai politik, parlemen, komisi-komisi negara, kementerian-kementerian, birokrasi, lembaga-lembaga pendidikan, lembaga-lembaga penegak hukum, rumah tagga, masyarakat adat, dan lain-lain. Oleh karena muncul di semua kelompok dan dimensi kehidupan sosial, maka tak heran kalau ia pun hadir dalam keputusan-keputusan politik, kebijakan-kebijakan, program-program, dan proyekproyek negara.

Bagi parlemen, pengawasan yang responsif gender dapat diletakkan dalam konteks keputusan-keputusan politik dan kebijakan-kebijakan yang dilahirkan dan diperdebatkan di parlemen. Dalam konteks ini, terdapat sejumlah indikator dalam pembentukan dan pelaksanaan peraturan perundang-undangan - untuk 
menjadi acuan parlemen dalam membuat di mana pengawasan yang dilakukannya responsif gender.

\begin{tabular}{|c|c|c|c|}
\hline Dimensi & \multicolumn{2}{|r|}{ Materi } & Dasar Hukum \\
\hline \multirow{5}{*}{ Prinsip } & $\mathrm{a}$ & Persamaan Substantif: & \multirow{5}{*}{$\begin{array}{c}\text { Hak Konstitusi } \\
\text { dan } \\
\text { Konvensi } \\
\text { CEDAW }\end{array}$} \\
\hline & & 1. Persamaan hak; & \\
\hline & & 2. Persamaan kesempatan; dan & \\
\hline & & 3. Persamaan akses. & \\
\hline & $\mathrm{b}$ & Non diskriminatif. & \\
\hline \multirow{4}{*}{ Asas } & $\mathrm{a}$ & Pengayoman; & \multirow{4}{*}{ UU 12/2011 } \\
\hline & $\mathrm{b}$ & Kemanusiaan; & \\
\hline & $\mathrm{c}$ & Keadilan; dan & \\
\hline & $\mathrm{d}$ & Kesamaan dalam hukum dan pemerintahan. & \\
\hline \multirow{6}{*}{$\begin{array}{c}\text { Proses } \\
\text { Pembentukan }\end{array}$} & $\mathrm{a}$ & Partisipasi: & \multirow{6}{*}{$\begin{array}{l}\text { UU } 12 / 2011 \\
\text { tentang } \\
\text { Pembentukan } \\
\text { RUU dan } \\
\text { Peraturan Tata } \\
\text { Tertib }\end{array}$} \\
\hline & & 1. Kehadiran; & \\
\hline & & 2. Keterwakilan; dan & \\
\hline & & 3. Pengaruh. & \\
\hline & $\mathrm{b}$ & Terbuka; & \\
\hline & $\mathrm{c}$ & Transparan. & \\
\hline \multirow[t]{3}{*}{ Goal 5} & a & $\begin{array}{l}\text { Meningkatkan kualitas hidup dan peran peremuan } \\
\text { dalam pembangunan }\end{array}$ & \multirow{3}{*}{$\begin{array}{l}\text { Perpres No. } \\
\text { 2/2015 tentang } \\
\text { RPJMN III } \\
(2015-2019)\end{array}$} \\
\hline & $\mathrm{b}$ & $\begin{array}{l}\text { Meningkatkan perlindungan bagi perempuan dari } \\
\text { berbagai tindak kekerasan, termasuk tindak } \\
\text { pidana perdagangan orang. }\end{array}$ & \\
\hline & $\mathrm{c}$ & $\begin{array}{l}\text { Meningkatkan kapasitas kelembagaan PUG dan } \\
\text { perlindungan perempuan dari berbagai tindak } \\
\text { kekerasan. }\end{array}$ & \\
\hline \multirow{5}{*}{$\begin{array}{c}\text { Perubahan } \\
\text { Metodologi IPM }\end{array}$} & $\mathrm{a}$ & Angka Harapan Hidup saat Lahir (AHH). & \multirow{5}{*}{ UNDP } \\
\hline & $\mathrm{b}$ & Angka Harapan Lama Sekolah (HLS). & \\
\hline & $\mathrm{c}$ & Rata-rata Lama Sekolah RLS) 25 th +). & \\
\hline & $\mathrm{d}$ & 96 Komoditas PPP. & \\
\hline & $\mathrm{e}$ & Rata-rata Ukur/Geometrik. & \\
\hline \multirow{4}{*}{$\begin{array}{c}\text { Politik dan } \\
\text { Kemasyarakatan }\end{array}$} & $\mathrm{a}$ & Hak untuk memilih dan dipilih; & \multirow{4}{*}{$\begin{array}{l}\text { Konvensi } \\
\text { CEDAW }\end{array}$} \\
\hline & $\mathrm{b}$ & $\begin{array}{l}\text { Hak untuk berpartisipasi dalam perumusan } \\
\text { kebijakan dan implementasinya; }\end{array}$ & \\
\hline & $\mathrm{c}$ & $\begin{array}{l}\text { Hak untuk memegang jabatan dalam } \\
\text { pemerintahan dan melaksanakan fungsi } \\
\text { pemerintahan di semua tingkatan; dan }\end{array}$ & \\
\hline & $\mathrm{d}$ & $\begin{array}{l}\text { Hak untuk berpartisipasi dalam organisasi dan } \\
\text { perkumpulan non pemerintah yang berhubungan } \\
\text { dengan kehidupan masyarakat dan politik negara. }\end{array}$ & \\
\hline \multirow{3}{*}{$\begin{array}{l}\text { Kewarga- } \\
\text { negaraan }\end{array}$} & a & $\begin{array}{l}\text { Hak untuk memperoleh, mengubah, atau } \\
\text { mempertahankan kewarganegaraan; }\end{array}$ & \multirow{3}{*}{$\begin{array}{l}\text { Konvensi } \\
\text { CEDAW }\end{array}$} \\
\hline & $\mathrm{b}$ & $\begin{array}{l}\text { Jaminan bahwa perkawinan dengan orang asing } \\
\text { maupun perubahan kewarganegaraan oleh suami } \\
\text { selama perkawinan tidak secara otomatis } \\
\text { mengubah kewarganegaraan isteri, } \\
\text { menjadikannya tidak berkewarganegaraan atau } \\
\text { tidak memaksakan keewarnegaraan suami } \\
\text { kepadanya; dan }\end{array}$ & \\
\hline & $\mathrm{c}$ & $\begin{array}{l}\text { Hak yang sama dengan laki-laki berkenaan } \\
\text { dengan kewarganegaraan anak-anak mereka. }\end{array}$ & \\
\hline \multirow[t]{2}{*}{ Pendidikan } & \multicolumn{2}{|r|}{ Hak yang sama dengan laki-laki di bidang pendidikan. } & $\begin{array}{l}\text { Konvensi } \\
\text { CEDAW }\end{array}$ \\
\hline & $\mathrm{a}$ & Hak untuk bekerja sebagai hak asasi manusia; & \\
\hline
\end{tabular}




\begin{tabular}{|c|c|c|c|}
\hline \multirow{5}{*}{ Ketenagakerjaan } & $\mathrm{b}$ & Hak atas kesempatan kerja yang sama; & \multirow{5}{*}{$\begin{array}{l}\text { Konvensi } \\
\text { CEDAW }\end{array}$} \\
\hline & $\mathrm{c}$ & $\begin{array}{l}\text { Hak untuk memilih profesi dan pekerjaan, hak } \\
\text { untuk promosi, jaminan kerja, dan semua } \\
\text { tunjangan serta fasilitas kerja, hak untuk } \\
\text { memperoleh latihan kejuruan dan latihan ulang; }\end{array}$ & \\
\hline & $\mathrm{d}$ & Hak untuk menerima upah yang sama; & \\
\hline & $\mathrm{e}$ & Hak atas jaminan sosial; dan & \\
\hline & $\mathrm{f}$ & $\begin{array}{l}\text { Hak atas perlindungan kesehatan dan } \\
\text { keselamatan kerja. }\end{array}$ & \\
\hline \multirow{2}{*}{$\begin{array}{l}\text { Kesehatan dan } \\
\text { Keluarga } \\
\text { Berencana }\end{array}$} & $\mathrm{a}$ & $\begin{array}{l}\text { Hak atas pemeliharaan kesehatan dan jaminan } \\
\text { memperoleh pelayanan kesehatan, termasuk } \\
\text { keluarga berencana; dan }\end{array}$ & \multirow[t]{2}{*}{$\begin{array}{l}\text { Konvensi } \\
\text { CEDAW }\end{array}$} \\
\hline & $\mathrm{b}$ & $\begin{array}{l}\text { Jaminan untuk mendapatkan pelayanan yang } \\
\text { layak berkaitan dengan kehamilan, persalinan, } \\
\text { dan paksa persalinan. }\end{array}$ & \\
\hline \multirow[b]{2}{*}{ Ekonomi } & $\mathrm{a}$ & Hak atas tunjangan keluarga; dan & \multirow{2}{*}{$\begin{array}{l}\text { Konvensi } \\
\text { CEDAW }\end{array}$} \\
\hline & $\mathrm{b}$ & $\begin{array}{l}\text { Hak atas jaminan bank, hipotek, dan kredit } \\
\text { permodalan lainnya. }\end{array}$ & \\
\hline \multirow{5}{*}{ Hukum } & $\mathrm{a}$ & Hak yang sama di hadapan hukum; & \multirow{5}{*}{$\begin{array}{l}\text { Konvensi } \\
\text { CEDAW }\end{array}$} \\
\hline & $\mathrm{b}$ & $\begin{array}{l}\text { Hak dalam urusan-urusan sipil, seperti: } \\
\text { kecakapan hukum yang sama dengan laki-laki } \\
\text { serta kesempatan yang dalam menjalankan } \\
\text { kecakapan tersebut; }\end{array}$ & \\
\hline & $\mathrm{c}$ & $\begin{array}{l}\text { Hak untuk menandatangani kontrak dan } \\
\text { mengurus harta kekayaan; }\end{array}$ & \\
\hline & $\mathrm{d}$ & $\begin{array}{l}\text { Hak untuk mendapatkan perlakuan yang sama } \\
\text { pada semua tingkatan prosedur di muka hakim } \\
\text { dan pengadilan; dan }\end{array}$ & \\
\hline & e & $\begin{array}{l}\text { Hak yang sama berkenaan dengan hukum yang } \\
\text { berhubungan dengan mobilitas orang-orang dan } \\
\text { kebebasan memilih tempat tinggal dan domisili. }\end{array}$ & \\
\hline \multirow{7}{*}{ Perkawinan } & $\mathrm{a}$ & Hak untuk memasuki jenjang perkawinan; & \multirow{7}{*}{$\begin{array}{l}\text { Konvensi } \\
\text { CEDAW }\end{array}$} \\
\hline & $\mathrm{b}$ & $\begin{array}{l}\text { Hak untuk memilih sesuatu secara bebas dan } \\
\text { memasuki jenjang perkawinan hanya dengan } \\
\text { persetujuan bebas dan sepenuhnya; }\end{array}$ & \\
\hline & $\mathrm{c}$ & $\begin{array}{l}\text { Hak dan tanggung jawab yang sama sebagai } \\
\text { orangtua dalam urusan yang berhubungan dengan } \\
\text { anak-anak mereka; }\end{array}$ & \\
\hline & $\mathrm{d}$ & $\begin{array}{l}\text { Hak untuk menentukan secara bebas dan } \\
\text { bertanggung jawab jumlah dan jarak kelahiran } \\
\text { serta memperoleh informasi, pendidikan, dan } \\
\text { sarana yang memungkinkan mereka } \\
\text { menggunakan hak tersebut; }\end{array}$ & \\
\hline & $\mathrm{e}$ & $\begin{array}{l}\text { Hak dan tanggung jawab yang berkaitan dengan } \\
\text { perwalian, pemeliharaan, pengawasan, dan } \\
\text { pengangkatan anak; }\end{array}$ & \\
\hline & $\mathrm{f}$ & $\begin{array}{l}\text { Hak pribadi yang sama sebagai isteri, termasuk } \\
\text { hak untuk memilih nama keluarga, profesi, atau } \\
\text { jabatan; dan }\end{array}$ & \\
\hline & $\mathrm{g}$ & $\begin{array}{l}\text { Hak yang sama berkaitan dengan pemilikan, } \\
\text { perolehan, administrasi, penikmatan dan } \\
\text { pemindahtanganan harta benda yang ada. }\end{array}$ & \\
\hline
\end{tabular}

Tabel 1. Indikator-indikator dalam Pengawasan Parlemen Responsif Gender Sumber: Widodo dan Ronald Rofiandri (2015), dan Kementerian PP-PA RI (2015). 
Selain indikator-indikator yang ditampilkan pada matriks di atas, variabel lain yang menjadi fokus pengawasan perlemen yang responsif gender adalah soal anggaran. Format anggaran yang ada di (R)APBN/APBD serta alokasi dalam program-program pembangunan yang diajukan pemerintah mesti di-plototi dengan cermat agar ia mencerminkan anggaran yang responsif gender. Variabel ini sangat penting karena bisa berdampak sangat luas dalam kehidupan bernegara, berbangsa, dan bermasyarakat. Artinya, jika anggaran yang disusun tidak responsif gender, jangan berharap banyak akan ada upaya-upaya struktural yang kuat ke arah realisasi dan penguatan program-program bagi terciptanya keadilan dan kesetaraan gender.

Satu lagi variabel yang tidak kalah pentingnya sekaligus satu kesatuan dengan pengawasan adalah kegiatan legislasi di parlemen. Sebagai lembaga perwakilan, parlemen harus bisa memastikan bahwa legislasi yang dilakukan berada dalam lingkaran responsif gender. Rancangan Undang-Undang yang dibahas dan ditetapkan di parlemen harus dijamin tidak ada yang bias gender, tidak diskriminatif terhadap perempuan, dan tidak menambrak prinsip-prinsip keadilan gender. Bagaimanapun keputusan-keputusan politik yang dihasilkan parlemen seperti UU pada gilirannya akan memengaruhi kehidupan bernegara, berbangsa, dan bermasyarakat.

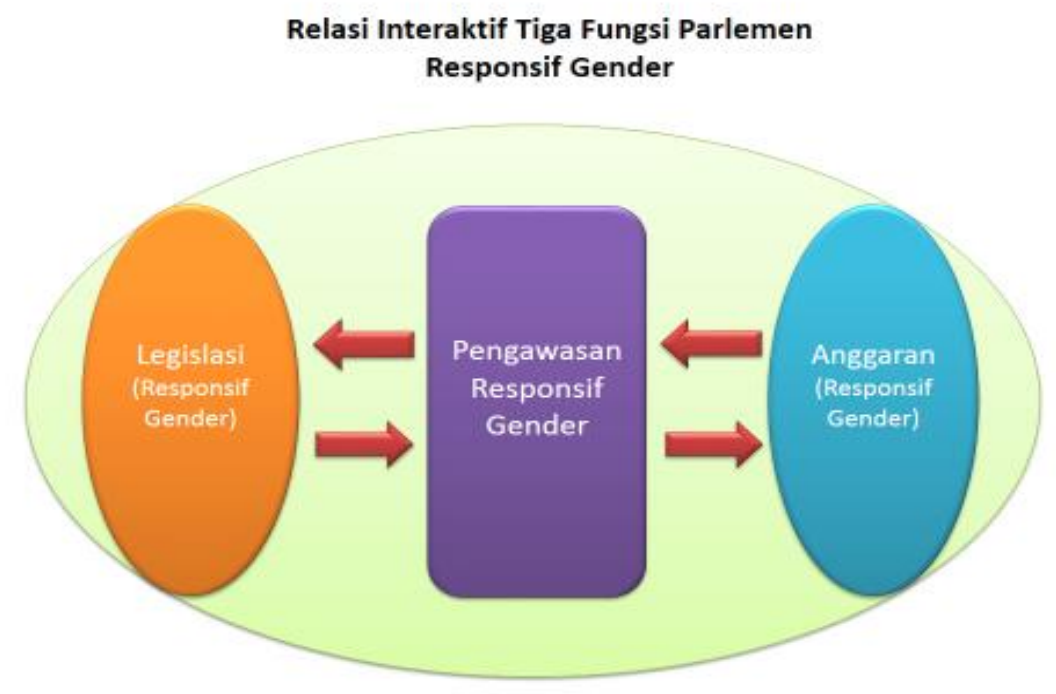

Tetapi, penting disadari akan hambatan-hambatan yang sangat mungkin muncul di internal parlemen dalam membangun pengawasan responsif gender. Hambatan-hambatan itu di antaranya: pertama, tingkat pengetahuan dan wawasan anggota parlemen tentang gender masih rendah. Hal ini setidaknya tercermin dari keputusan-keputusan politik produk parlemen yang sangat bias gender. Kedua, terlalu sedikit anggota parlemen dari kalangan perempuan. Hasil Pemilu 2014, misalnya, perempuan yang terpilih sebagai anggota parlemen sekitar 17 persen dari total anggota DPR RI. Perempuan anggota DPD sekitar 26 persen (namun 
terdapat 11 provinsi yang tidak memiliki wakil peremuan di DPD), dan di tingkat daerah, perempuan anggota di DPRD Provinsi/Kabupaten/Kota rata-rata hanya 14 persen. ${ }^{15}$ Jumlah yang sedikit itu belum tentu pula memahami problem gender dan isu-isu sensitifitas gender.Lebih prihatin jika, misalnya, mereka ternyata juga tidak memiliki kemampuan berbicara yang baik, tidak pandai berdebat, dan tidak punya ketegasan sikap soal gender. Ketiga, anggota parlemen tidak memiliki informasi yang cukup, akurat, dan tepercaya soal isu-isu gender. Keempat, anggota parlemen bersikap cuek dan sikap tidak mau tahu terhadap isu-isu gender akibat lemahnya arus ideologi sensitifitas gender pada diri mereka.

Hambatan-hambatan tersebut bukan sesuatu yang mustahil terjadi, dan nyata adanya. Menurut Carver, dalam banyak konteks, seseorang menemukan bahwa referensi terhadap gender adalah referensi untuk perempuan, seolah-olah laki-laki dan maskulinitas semuanya tidak bermasalah dalam hal itu, atau mungkin tidak ada hubungannya sama sekali dengan jenis kelamin. Hal ini dapat dengan mudah menjadi cara membuat perempuan bermasalah, dengan cara yang meminggirkan mereka sebagai 'masalah'. ${ }^{16}$ Kondisi seperti dikatakan Carver itu bisa saja terjadi di parlemen kita. Tidak menutup kemungkinan, misalnya, para anggota parlemen memandang tak ada masalah lagi dengan gender di negeri ini.

Pertanyaannya, bagaimana mengatasi hambatan-hambatan itu? Setidaknya ada tiga program yang dapat dan perlu dilakukan. Pertama, mendorong, berkampanye terus-menerus, serta melakukan advokasi bagi upaya memperbanyak jumlah perempuan yang terpilih - melalui pemilihan umum sebagai anggota parlemen baik di tingkat nasional maupun daerah-daerah. Hal ini menjadi program jangka panjang dan berlangsung dalam rentang waktu yang cukup lama, bahkan bergenerasi. Kedua, menuntut dan mendorong lembaga parlemen memberikan dukungan struktural yang kuat, sistematis, dan berkelanjutan bagi keputusan-keputusan politik dan kebijakan-kebijakan responsif gender. Ketiga, memberikan penguatan dan pelatihan-pelatihan kepada semua anggota parlemen (laki-laki maupun perempuan) di tingkat nasonal dan daerah-daerah tentang pengetahuan gender dengan spesifik pada tema "Parlemen Responsif Gender".

\section{PENUTUP}

Pengawasan parlemen terhadap pemerintah menjadi salah satu fungsi utama parlemen. Pengawasan penting dilakukan, tidak saja sebagai upaya menjaga praktik-praktik kekuasaan dari penyelewengan-penyelewengan, juga

\footnotetext{
15 Lihat, Kementerian PP-PA Republik Indonesia. 2015. Grand Design Peningkatan Keterwakilan Perempuan di Dewan Perwakilan Rakyat, Dewan Perwakilan Daerah, dan Dewan Perwakilan Rakyat Daerah pada Pemilu 2019. Jakarta: Kementerian PP-PA RI, hlm. 28-30.

16 Terrell Carver. 2002. "A Political Theory of Gender: Perspectives on the "Universal Subject", dalam Vicky Randall and Georgina Waylen (eds.), Gender, Politics and the State. London. Routledge, hlm. 19.
} 
untuk menjamin akuntabilitas penyelenggaraan negara. Parlemen yang kuat dan reprsentatif, tidak hanya mampu melahirkan keputusan-keputusan politik yang merefleksikan kepentingan publik, melainkan juga mampu mengawasi pemerintah untuk tidak menyalahgunakan kekuasaan dan kewenangan politik yang dimilikinya.

Parlemen kita - baik di tingkat nasional maupun daerah - menunjukkan kecenderungan yang lemah dalam menjalankan fungsi pengawasan. Di era Orde Baru, pengawasan lemah karena sistem politik yang otoritarian dan parlemen takut kepada pemerintah (eksekuitif) yang umumnya dari militer (sekaligus bagian dari Golongan Karya). Sementara di era reformasi, pengawasan lemah lebih karena parlemen: [i] bergantung pada eksekutif, dan kualitas sumberdaya manusia (anggota parlemen) umumnya berada di bawah pejabat-pejabat eksekutif; dan [ii] menjalin kolusi (kesepakatan jahat) dengan eksekutif, umumnya berupa perekayasaan anggaran untuk kepentingan dirinya sendiri. Faktor ini sekaligus yang membuat banyak anggota parlemen, kepala daerah, dan pejabat birokrasi ditangkap pihak penegak hukum (terutama Komisi Pemberantasan Korupsi) dengan tuduhan menyelewengkan anggaran.

Kondisi demikian menyulitkan bahkan menghilangkan kewibawaan parlemen dalam melakukan pengawasan. Ibarat "kepala tak berani tegak dan lidah tak dapat berucap, karena dalam posisi maling teriak maling”. Kondisi ini pula yang sekaligus memberi andil bagi kecilnya arus pengawasan parlemen yang responsif gender. Karena itu, pengawasan parlemen responsif gendermasih harus dan terus-menerus dikampanyekan serta diperjuangkan. Tidak cukup kalau sekadar hitungan dari satu periode ke periode berikut atau satu pemilu ke pemilu berikut, melainkan dalam hitungan generasi. Wallahu 'alam.

\section{DAFTAR PUSTAKA}

Abdullah, Irwan. (2001). Seks, Gender \& Reproduksi Kekuasaan. Yogyakarta: Tarawang.

Aziz SR, Abdul. (2015). Partisipasi Perempuan dalam Pengawasan Pembangunan: Sebuah Panduan Aksi. Jakarta: Kementerian PP-PA Republik Indonesia.

Budiardjo, Miriam. (2008). Dasar-dasar Ilmu Politik. Jakarta: Gramedia Pustaka Utama.

Carver, Terrell. (2002). "A Political Theory of Gender: Perspectives on the 'Universal Subject'", dalam Vicky Randall and Georgina Waylen (eds.), Gender, Politics and the State. London. Routledge.

Carver, Terrell. (2005). "Sexual Citizenship Gendered and Degendered Narratives", dalam Terrell Carver and Véronique Mottier (eds.),Politics of Sexuality Identity, Gender, Citizenship. London: Routledge.

De Bauevoir, Simone. (2010). The Second Sex. New York: Alfred A. Knopf. 
Faqih, Mansour. (1996). Analisis Gender \& Transformasi Sosial. Yogyajarta: Pustaka Pelajar.

Gerung, Rocky, Siti Nurjannah, dan Darsono Sudibyo. (2015). Gender dan Parlemen. Jakarta: UNDP Indonesia.

Heywood, Andrew. (2014). Politik (terjemahan). Yogyakarta: Pustaka Pelajar.

Isjwara, F. (1999). Pengantar Ilmu Politik. Bandung: Putrabardin.

Kementerian Pemberdayaan Perempuan dan Perlindngan Anak Republik Indonesia. (2015). Goal 5 dan The Global Goals for Sustainable Development. Jakarta: Kementerian PP-PA RI.

Kementerian Pemnberdayaan Perempuan dan Perlindungan Anak Republik Indonesia. (2015). Grand Design Peningkatan Keterwakilan Perempuan di Dewan Perwakilan Rakyat, Dewan Perwakilan Daerah, dan Dewan Perwakilan Rakyat Daerah pada Pemilu 2019. Jakarta: Kementerian PP-PA RI.

Newton K. dan J.W. Van Deth. (2010). Foundations of Comparative Politics (second edition).Cambridge: Cambridge University Press.

Peraturan DPD RI Nomor 1 Tahun 2014 tentang Tata Tertib.

Peraturan DPR RI Nomor 1 Tahun 2014 tentang Tata Tertib.

Peraturan DPR RI Nomor 3 Tahun 2016 tentang Perubahan Kedua atas Peraturan DPR RI No. 1 Tahun 2014 tentang Tata Tertib.

Piao, Alvin Lie Ling, dkk. 2015. Buku Panduan Penguatan Kapasitas Perempuan Anggota Legislatif melalui Kasus-kasus. Jakarta: UNDP Indonesia.

UUD Negara Republik Indonesia Tahun 1945.

UU No. 17 Tahun 2014 tentang MPR, DPR, DPD, dan DPRD.

UU No. 32 Tahun 2004 tentang Pemerintahan Daerah.

Widodo dan Ronald Rofiandri. 2015. Pengawasan DPR, DPD, dan DPRD. Jakarta: Kementerian PP-PA Republik Indonesia. 
----------------------- 